https://nv.nltu.edu.ua

https://doi.org/10.15421/40281013

$@ \bowtie$ Correspondence author

Article received 08.10.2018 p.

Article accepted 29.11.2018 p.

M. V. Ruda

УДК 66.047 .45

marichkarmv@gmail.com

О. Г. Чайка', О. О. Мачьків ${ }^{1}$, О. В. Стокалюк', М. В. Руда'

${ }^{1}$ Національний університет "Львівська політехніка", м. Львів, Украӥна 2 Львівський державний університет безпеки життєдіяльності, м. Львів, Украйна

\title{
ДОСЛІДЖЕННЯ ВМІСТУ ВАЖКИХ МЕТАЛІВ У ГРУНТІ НА ПРИЛЕГЛИХ ТЕРИТОРІЯХ АВТОЗАПРАВНИХ СТАНЦІЙ
}

Визначено вміст важких металів на прилеглих територіях автозаправних станцій. Встановлено, що забруднення поверхні землі транспортними викидами поблизу та на автозаправній станції нагромаджується поступово, залежно від кількості автотранспорту, що проїжджає через прилеглу трасу, дорогу, магістраль та заїжджає безпосередньо на автозаправні станції і зберігається дуже довго навіть після ліквідації дорожнього полотна. Підвищення екологічної та аварійної безпеки під час експлуатації автозаправних станцій разом з виконанням заходів зі зниження забруднення вод і грунтів потребує проведення контролю рівня концентрацій небезпечних речовин для унеможливлення перевищення санітарних, екологічних та вибухонебезпечних норм. Очевидно, що безумовною вимогою експлуатації автозаправних станцій є оцінювання впливу на навколишнє середовище забруднювальних речовин з визначенням їх концентрацій. Виявлено, що ступінь забруднення довкілля хімічними елементами, і передусім важкими металами, визначається відносно фонового вмісту елементів або гранично допустимої концентрації. З'ясовано, що основними забруднювальними металами, які можуть негативно впливати на господарську діяльність у прилеглих територіях і спричинять негативний вплив на здоров'я людини, $є$ цинк та хром. Встановлено шкалу оцінки екологічної небезпеки забруднення ландшафтів автозаправними станціями. Запропоновано для підвищення екологічної безпеки автозаправних станцій здійснювати постійний моніторинг грунтового покриву в межах санітарно захисної зони та на прилеглих територіях, посилити вимоги до очисних та ресурсоощадних систем та забезпечити виконання плану обов'язкової періодичної технічної діагностики обладнання автозаправних станцій.

Ключові слова: автозаправні станції; важкі метали; забруднювальні речовини; полютанти; фонова концентрація; забруднені грунти.

Вступ. Особливе місце серед проблем, пов'язаних 3 екологічним станом довкілля, займають проблеми контролю забруднення навколишнього середовища, зокрема вод і грунтів поблизу автозаправних станцій (АЗС). Проблема забруднення грунтів та поверхневих вод під час роботи АЗС тісно пов'язана з бурхливим ростом автомобілізації країни. Кожна автозаправна станція є джерелом викиду шкідливих і небезпечних речовин. При цьому за останні роки істотно збільшилась кількість АЗС, розташованих у приміській смузі, житлових кварталах, безпосередньо біля великих торгових і розважальних комплексів. Постійне зростання кількості АЗС, а також об'ємів реалізованого пального, потребує детального підходу до вивчення впливу роботи АЗС на навколишне середовище. Автозаправні станції на сьогодні входять до основних джерел забруднення навколишнього середовища.

Підвищення екологічної та аварійної безпеки під час експлуатації АЗС разом з виконанням заходів зі зни- ження забруднення вод і грунтів потребує проведення контролю рівня концентрацій небезпечних речовин для унеможливлення перевищення санітарних, екологічних та вибухонебезпечних норм. Очевидно, що безумовною вимогою експлуатації автозаправних станцій є оцінювання впливу на навколишнє середовище забруднювальних речовин з визначенням ї концентрацій (Radomska, 2010).

Постановка проблеми. Зростання попиту на послуги АЗС та жорстка конкуренція серед нафтотрейдерів призводять до нарощування мережі АЗС, iї максимального наближення до споживачів, забезпечення цілодобової роботи та збільшення обсягу послуг. Все це збільшує техногенне навантаження у містах і розширює діапазон негативних впливів на навколишнє середовище.

Невідповідне проектування і будівництво комунікаційних систем, недосконала ізоляція резервуарів, аварійні ситуації, порушення правил виконання технологічних процесів призводять до надходження в навко-

Інформація про авторів:

Чайка Оксана Григорівна, канд. техн. наук, ст. викладач, кафедра екологічної безпеки та природоохоронної діяльності.

Email: okcanachajka@gmail.com

Мацьків Олена Олександрівна, канд. техн. наук, асистент, кафедра цивільної безпеки. Email: o.olex.ul@gmail.com

Стокалюк Олег Володимирович, канд. техн. наук, доцент, кафедра інженерного забезпечення саперних та піротехнічних робіт.

Email: stokoleg@gmail.com

Руда Марія Віталіївна, канд. техн. наук, асистент, кафедра екологічної безпеки та природоохоронної діяльності. Email: marichkarmv@gmail.com

Цитування за ДСтУ: Чайка О. Г., Мацьків О. О., Стокалюк О. В., Руда М. В. Дослідження вмісту важких металів у ґрунті на прилеглих територіях автозаправних станцій. Науковий вісник НлтУ України. 2018, т. 28, № 10. С. 62-65.

Citation APA: Chaika, O. G., Matskov, O. O., Stokalyuk, O. M., Ruda, M. V. (2018). Study of heavy metals content in the soil of adjacent territories of petrol stations. Scientific Bulletin of UNFU, 28(10), 62-65. https://doi.org/10.15421/40281013 
лишнє середовище токсичних речовин, небезпечних для працівників АЗС та мешканців прилеглих територій (Hryshko et al., 2012; Zaporozhets et al., 2017).

Незважаючи на широке розповсюдження АЗС, комплексної оцінки їхнього впливу на навколишнє середовище досі не здійснено. Проте саме з цими об'єктами пов'язане надходження забруднювачів у повітря, грунт і підземні води та їх подальша міграція у відкриті водні об'єкти (Hryshko et al., 2012).

Аналіз останніх досліджень і публікацій. Забруднення навколишнього середовища поблизу місць розміщення АЗС та автомагістралей досліджено останнім часом у працях (Radomska, 2010; Sheikina \& Mysliuk, 2008). У зазначених роботах особливу увагу приділено визначенню концентрації важких металів ( $\mathrm{Pb}, \mathrm{Mn}, \mathrm{Cd}$, $\mathrm{Cu}, \mathrm{Zn})$ у грунтовому покриві вздовж транспортних магістралей індустріально-урбанізованих територій (Hryshko et al., 2012; Swinomatkawordpress, 2018; Franchuk \& Radomska, 2009; Bilyk et al., 2009).

Забруднення поверхні землі транспортними викидами поблизу та на автозаправній станції нагромаджується поступово, залежно від кількості автотранспорту, що проїжджає через прилеглу трасу, дорогу, магістраль та заїжджає безпосередньо на АЗС, і зберігається дуже довго, навіть після ліквідації дорожнього полотна (закриття дороги, траси, магістралі, або повна ліквідація шляху та асфальтного покриття) (Franchuk \& Radomska, 2009). Для майбутнього покоління, яке найімовірніше відмовиться від автомобілів у їх сучасному вигляді, транспортне забруднення грунтів стане найболючішим і найважчим наслідком минулого. Можливо, що навіть під час ліквідації побудованих нашим поколінням доріг, забруднений металами та канцерогенами грунт доведеться просто прибирати з поверхні.

Різні хімічні елементи, особливо метали, що нагромаджуються у грунтах, засвоюють рослини і через них по харчовому ланцюгу переходять в організм тварин i людини. Частина 3 них розчиняється і виноситься грунтовими водами, потім потрапляє в річки, водойми і вже через питну воду може потрапити у людський організм (Bilyk et al., 2009).

Мета роботи - визначити вміст важких металів на прилеглих територіях АЗС.

Результати дослідження та їх обговорення. Ступінь забруднення довкілля хімічними елементами, і передусім важкими металами, визначається відносно фонового вмісту елементів або гранично допустимої концентрації (ГДК) у ньому.

У разі високого ступеня забруднення грунтів відбувається не тільки процес зміни та перебудови співвідношення мікроорганізмів, яке дуже сильно відрізняється від незабрудненого, але й зміна деяких хімічних та фізичних властивостей грунту. Доти, доки важкі метали міцно зв'язані зі складовими частинами грунту і важкодоступні, їх негативний вплив на грунт і навколишне середовище буде незначним. Проте, якщо грунтові умови сприяють переходу важких металів у грунтовий розчин, з'являється пряма загроза забруднення грунтів, виникає можливість їх проникнення в рослини, а також в організми людей і тварин, які споживають ці рослини. Окрім цього, важкі метали можуть бути забруднювачами рослин і водоймищ внаслідок використання мулу стічних вод. Загроза забруднення грунтів і рослин залежить від виду рослин, форм хімічних сполук у грунті, наявності елементів, що протидіють впливу важких металів і речовин, які утворюють 3 ними комплексні сполуки, адсорбції і десорбції, кількості доступних форм цих металів у грунті та грунтово-кліматичних умов. Отже, негативний вплив важких металів істотно залежить від їх рухомості, тобто розчинності (Bilyk et al., 2009).

У разі середнього ступеня забруднення вміст важких металів впливає тільки на грунтову біоту. У грунті починаються процеси перерозподілу різних груп мікроорганізмів та їх адаптація до умов забруднення (Sheikina \& Mysliuk, 2008).

Процес визначення елементного складу важких металів у відібраних пробах грунтів здійснювали у навчально-науковій лабораторії екологічного контролю та експертизи Національного університету "Львівська політехніка" в Інституті сталого розвитку ім. В. Чорновола, на флуоресцентному аналізаторі EXPERT-3L. Дослідження грунтів здійснювали у 8 місцях навколо АЗС, на відстані 50 та 100 м.

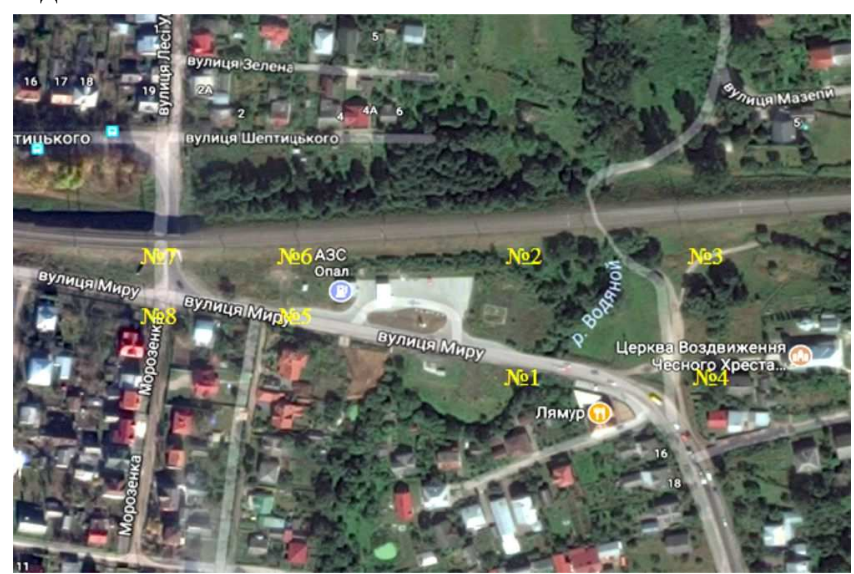

Рис. 1. Мапа відбору проб грунту в с. Зимна вода

За результатами досліджень встановлено вміст хімічних елементів у відібраних зразках грунту. Результати подано у табл. 1. Оскільки основною метою цієї роботи визначення вмісту важких металів у грунтах, для наступних розрахунків використовували лише значення їх концентрацій.

Табл. 1. Показники вмісту хімічних елементів у грунтах

\begin{tabular}{|c|c|c|c|c|c|c|c|c|c|c|}
\hline $\begin{array}{c}\text { 孚 } \\
\text { 号 }\end{array}$ & \multicolumn{10}{|c|}{ Вміст хімічних елементів у грунтах, мг/кг } \\
\hline & $\mathrm{Cu}$ & $\mathrm{Zn}$ & $\mathrm{Sr}$ & $\mathrm{Zr}$ & $\mathrm{Pb}$ & $\mathrm{Cr}$ & $\mathrm{Sn}$ & $\mathrm{V}$ & $\mathrm{Ti}$ & $\mathrm{Fe}$ \\
\hline 1 & 740 & 900 & 950 & 3680 & 690 & 420 & 730 & 630 & 21070 & 170340 \\
\hline 2 & 910 & 2180 & 1030 & 3150 & 720 & 600 & 330 & 960 & 28050 & 206560 \\
\hline 3 & 230 & 1470 & 900 & 3280 & 710 & 620 & 790 & & 24160 & 100430 \\
\hline 4 & - & 850 & 1030 & 2980 & 610 & 3300 & 670 & & 25380 & 106480 \\
\hline 5 & 530 & 3190 & 680 & 2530 & 560 & - & 570 & & 24070 & 79730 \\
\hline 6 & 960 & 710 & - & 500 & - & 720 & - & & 3140 & 789080 \\
\hline 7 & 450 & 1570 & 1120 & 2850 & 760 & 470 & 530 & & 23010 & 152580 \\
\hline 8 & 210 & 540 & 630 & 1170 & 450 & - & - & 560 & 15460 & 70060 \\
\hline
\end{tabular}

Оцінювання небезпечності забруднення грунтів хімічними елементами проводили за показником коефіцієнта концентрації хімічних елементів $\left(K_{c}\right)$, інтенсивністю забруднення $P_{j}$, а також за шкалою оцінки екологічної небезпеки, градацію якої розроблено на підставі вивчення стану здоров'я населення, що мешкає на територіях 3 різними рівнями забрудненості грунтів (табл. 2). Коефіцієнт концентрації хімічних елементів у грунтах, який характеризується співвідношенням вмісту хімічного елемента у грунтовому покриві до його фонового значення, розраховано за такою формулою:

$$
K_{c}=C_{i} / \Phi_{i}
$$


де: $C_{i}$ - вміст хімічного елемента в конкретному об'єкті, мг/кг; $\Phi_{i}-$ фоновий вміст хімічного елемента у грунті, мг/кг (табл. 3). Результати розрахунків подано в табл. 4.

Табл. 2. Шкала оцінки екологічної небезпеки забруднення грунтів

\begin{tabular}{|c|c|c|c|}
\hline $\begin{array}{l}\text { № } \\
\text { 3/ }\end{array}$ & $\begin{array}{l}\text { Категорія } \\
\text { інтенсив- } \\
\text { ності заб- } \\
\text { руднення } \\
\text { грунтів } \\
\end{array}$ & $\begin{array}{l}\text { Інтенсив- } \\
\text { ність заб- } \\
\text { руднення } \\
\text { грунту, } P_{j}\end{array}$ & $\begin{array}{c}\text { Зміна показників здоров'я } \\
\text { населення }\end{array}$ \\
\hline 1 & Допустима & Менше 15 & $\begin{array}{c}\text { Найнижчий рівень захворюва- } \\
\text { ності, мінімальна частота фун- } \\
\text { кціональних відхилень }\end{array}$ \\
\hline 2 & Безпечна & $16-30$ & $\begin{array}{c}\text { Збільшення загальної захворю- } \\
\text { ваності населення }\end{array}$ \\
\hline 3 & Небезпечна & $31-50$ & $\begin{array}{c}\text { Збільшення загальної захворю- } \\
\text { ваності, хронічні захворюван- } \\
\text { ня, порушення функціонально- } \\
\text { го стану серцево-судинної сис- } \\
\text { теми } \\
\end{array}$ \\
\hline 4 & $\begin{array}{c}\text { Дуже } \\
\text { небезпечна }\end{array}$ & Більше 50 & $\begin{array}{c}\text { збільшення загальної захворю- } \\
\text { ваності дітей, порушення реп- } \\
\text { родуктивної функції жінок }\end{array}$ \\
\hline
\end{tabular}

Табл. 3. Значення фонового вмісту мікроелементів

\begin{tabular}{|c|c|c|}
\hline № & Назва металу & $\begin{array}{c}\text { Фоновий вміст хімічних } \\
\text { елементів у грунті, мг/кг }\end{array}$ \\
\hline 1 & $\mathrm{Cu}$ & 200 \\
\hline 2 & $\mathrm{Zn}$ & 250 \\
\hline 3 & $\mathrm{Sr}$ & 1000 \\
\hline 4 & $\mathrm{Zr}$ & 2150 \\
\hline 5 & $\mathrm{Rb}$ & 420 \\
\hline 6 & $\mathrm{Cr}$ & 300 \\
\hline 7 & $\mathrm{Sn}$ & 420 \\
\hline 8 & $\mathrm{Ti}$ & 19290 \\
\hline 9 & $\mathrm{Fe}$ & 72700 \\
\hline
\end{tabular}

Табл. 4. Результати розрахунків

\begin{tabular}{|c|c|c|c|c|c|c|c|c|c|}
\hline $\begin{array}{c}\text { № } \\
\text { 3/п }\end{array}$ & \multicolumn{10}{|c|}{ Коефіцієнт концентрації хімічних елементів у грунті $K_{c}$} \\
\hline & $\mathrm{Cu}$ & $\mathrm{Zn}$ & $\mathrm{Sr}$ & $\mathrm{Zr}$ & $\mathrm{Pb}$ & $\mathrm{Cr}$ & $\mathrm{Sn}$ & $\mathrm{Ti}$ & $\mathrm{Fe}$ \\
\hline 1 & 3,7 & 3,6 & 0,95 & 1,71 & 1,64 & 1,4 & 1,74 & 1,09 & 2,34 \\
\hline 2 & 4,55 & 8,72 & 1,03 & 1,46 & 1,71 & 2 & 0,78 & 1,45 & 2,84 \\
\hline 3 & 1,15 & 5,88 & 0,9 & 1,52 & 1,69 & 2,06 & 1,88 & 1,25 & 1,38 \\
\hline 4 & - & 3,4 & 1,03 & 1,39 & 1,45 & 11 & 1,59 & 1,31 & 1,46 \\
\hline 5 & 2,65 & 12,76 & 0,68 & 1,18 & 1,33 & - & 1,35 & 1,24 & 1,09 \\
\hline 6 & 4,8 & 2,84 & - & 0,23 & - & 2,4 & - & 0,16 & 10,85 \\
\hline 7 & 2,25 & 6,28 & 1,12 & 1,32 & 1,8 & 1,56 & 1,26 & 1,19 & 2,1 \\
\hline 8 & 1,05 & 2,16 & 0,63 & 0,54 & 1,07 & - & - & 0,80 & 0,96 \\
\hline
\end{tabular}

Інтенсивність забруднення грунтів розраховано згідно 3 формулою (2), з урахуванням показника коефіцієнта концентрації хімічних елементів, помножений на коефіцієнт класу небезпечності кожного елемента:

$$
P_{j}=\sum\left(K_{c} \times M_{i}\right)
$$

де: $K_{c}-$ коефіцієнт концентрації мікроелемента; $M_{i}$ значення індексу небезпеки (табл. 5).

Табл. 5. Значення індексу небезпеки важких металів

\begin{tabular}{|c|c|c|}
\hline Клас & Мікроелементи & $\begin{array}{c}\text { Значення індексу } \\
\text { небезпеки Мi }\end{array}$ \\
\hline I & $\begin{array}{c}\mathrm{Pb}, \mathrm{Cd}, \mathrm{Hg}, \mathrm{F}, \mathrm{Zn}, \mathrm{As}, \mathrm{Se}, \\
\text { бенз(a)пірен }\end{array}$ & 4,1 і більше \\
\hline II & $\mathrm{Cu}, \mathrm{Co}, \mathrm{Cr}, \mathrm{Ni}, \mathrm{Mo}, \mathrm{Sb}, \mathrm{B}, \mathrm{Mn}$ & $2,6-4$ \\
\hline III & $\mathrm{V}, \mathrm{Ba}, \mathrm{Mn}, \mathrm{Sr}, \mathrm{AI}$ & $0,1-2,5$ \\
\hline
\end{tabular}

У табл. 6 подано дані розрахунку інтенсивності забруднення грунтів $P_{j}$ для кожного хімічного елемента.

Згідно з нашими розрахунками встановлено, що основними забруднювальними елементами, які можуть негативно впливати на господарську діяльність у прилеглих територіях АЗС і сприяти негативному впливу на здоров'я людини, є цинк і хром. Оскільки цинк, згідно зі значенням інтенсивності забруднення $P_{j}$, для $\mathrm{Zn}(\min )=8,86$ та $\mathrm{Zn}(\max )=52,32$ відповідає, за шкалою оцінки екологічної небезпеки забруднення ландшафтів, - чотирьом зонам, а саме: 8,86-15 - допустима; 16-30помірно небезпечна; 31-50 - небезпечна; 50-52,32 - дуже небезпечна. Аналогічно, щодо хрому: $\mathrm{Cr}(\mathrm{min})=5,6$, $\operatorname{Cr}(\max )=44$, тому категорії небезпечності за хромом відповідають трьом зонам -5,6-15- допустима;16-30помірно небезпечна; 31-44 - небезпечна.

Табл. 6. Інтенсивність забруднення грунтів $\mathbf{P}_{\text {i }}$

\begin{tabular}{|c|c|c|c|c|c|c|c|c|c|}
\hline \multirow{2}{*}{$\begin{array}{c}\text { № } \\
\text { 3/п }\end{array}$} & \multicolumn{7}{|c|}{ Інтенсивність забруднення грунтів $P_{j}$} \\
\hline 1 & 14,8 & 14,76 & 2,37 & 4,27 & 6,72 & 5,6 & 4,35 & 2,73 & 5,85 \\
\hline 2 & 18,2 & 35,75 & 2,57 & 3,65 & 7,01 & 8 & 1,95 & 3,63 & 7,1 \\
\hline 3 & 4.6 & 24,1 & 2,25 & 3,8 & 6,93 & 8,24 & 4,7 & 3,13 & 3,45 \\
\hline 4 & - & 13,94 & 2,57 & 3,47 & 5,94 & 44 & 3,97 & 3,28 & 3,65 \\
\hline 5 & 10,6 & 52,32 & 1,7 & 2,95 & 5,45 & - & 3,37 & 3,1 & 2,73 \\
\hline 6 & 19,2 & 11,64 & - & 0,57 & - & 9,6 & - & 0,4 & 27,13 \\
\hline 7 & 9 & 25,75 & 2,8 & 3,3 & 7,38 & 6,24 & 3,15 & 2,98 & 5,25 \\
\hline 8 & 4,2 & 8,86 & 1,57 & 1,35 & 4,39 & - & - & 2 & 2,4 \\
\hline
\end{tabular}

Висновки. Аналізуючи отримані дані, можна зазначити, що найбільшу концентрацію цинку виявлено у поверхневих зразках грунту (проби № 2, 3 та 5), що розміщені на відстані 50 та 100 м від ССЗ (див. рисунок) та згідно з оцінковою шкалою інтенсивності забруднення перебувають у зонах небезпечній та дуже небезпечній, що спричиняє збільшення загальної захворюваності дітей, хронічні захворювання, порушення функціонального стану серцево-судинної системи, порушення репродуктивної функції жінок. Щодо хрому, то найбільшу його концентрацію виявлено у зразках проби № 4, що розміщена на відстані 100 м від С33. Отже, перевищення концентрації цих важких металів створює екотоксичну зону забруднення грунту та призводить до його деградації.

Для підвищення екологічної безпеки АЗС пропонуємо здійснювати постійний моніторинг грунтового покриву в межах санітарно-захисної зони та на прилеглих територіях, посилити вимоги до очисних та ресурсощадних систем та забезпечити виконання плану обов'язкової періодичної технічної діагностики обладнання АЗС.

\section{Перелік використаних джерел}

Bilyk, T. I., Shtyka, O. S., Padalka, A. O., \& Tsurkan, K. O. (2009). Ekotoksylohichna otsinka zabrudnennia na svynets gruntu ta roslynnosti bilia avtotozapravnykh stantsii. Naukoiemni tekhnolohii, 3, 1-3. [In Ukrainian].

Franchuk, G. M., \& Radomska, M. M. (2009). Otsiniuvannia zabrudnennia gruntiv naftoproduktamy vnaslidok diialnosti avtozapravnykh stantsii. Visnyk NAU, 1(38), 46-49. [In Ukrainian].

Hryshko, V. M., Syshchykov, D. V., Piskova, O. M., Danylchuk, O. V., \& Mashtaler, N. V. (2012). Vazhki metaly: nadkhodzhennia $v$ grunty, translokatsiia u roslynakh ta ekolohichna bezpeka. Donetsk: Donbas, 304 p. [In Ukrainian].

Radomska, M. M. (2010). Otsinka ekolohichnoi sytuatsii v zoni vplyvu AZS. Ekolohichna bezpeka derzhavy: Vseukr. nauk.-prakt. konf. studentiv ta aspirantiv, (pp. 195-196), April 27-28, Kyiv. Kyiv: NAU. [In Ukrainian].

Sheikina, O. Yu., \& Mysliuk, O. O. (2008). Ekolohichna otsinka zabrudnennia miskykh gruntiv vazhkymy metalamy vzdovzh osnovnykh transportnykh mahistralei mista Cherkasy. Ekolohiia dovkillia ta bezpeka zhyttiediialnosti, 1, 61-65. [In Ukrainian].

Swinomatkawordpress. (2018). Rynok Ukrainy: hravtsi, sfery vplyvu. Retrieved from: http://swinomatka.wordpress.com. [In Ukrainian].

Zaporozhets, O. I., et al. (Eds). (2017). Ekolohichna bezpeka derzhavy. Tezy dopovidei KhI Vseukrainskoi naukovo-praktychnoi konferentsii molodykh uchenykh i studentiv, (pp. 28-31) April 20, Kyiv. Kyiv: NAU. [In Ukrainian]. 


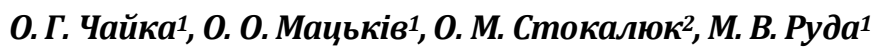

${ }^{1}$ Национальный университет "Львовская политехника", г. Львов, Украина

2 Львовский государственный университет безопасности жизнедеятельности, г. Львов, Украина

\title{
ИССЛЕДОВАНИЯ СОДЕРЖАНИЯ ТЯЖЕЛЫХ МЕТАЛЛОВ В ПОЧВЕ НА ПРИЛЕГАЮЩИХ
} ТЕРРИТОРИЯХ АВТОЗАПРАВОЧНЫХ СТАНЦИЙ

\begin{abstract}
Определено содержание тяжелых металлов на прилегающих территориях автозаправочных станций. Установлено, что загрязнение поверхности земли транспортными выбросами вблизи и на автозаправочной станции накапливается постепенно, в зависимости от количества автотранспорта, который проезжает через прилегающую трассу, дорогу, магистраль и заезжает непосредственно на автозаправочные станции, и сохраняется очень долго, даже после ликвидации дорожного полотна. Повышение экологической и аварийной безопасности при эксплуатации АЗС вместе с выполнением мероприятий по снижению загрязнения вод и почв требует проведения контроля уровня концентраций опасных веществ для предотвращения превышения санитарных, экологических и взрывоопасных норм. Очевидно, что безусловным требованием эксплуатации автозаправочных станций является оценка воздействия на окружающую среду загрязняющих веществ с определением их концентраций. Определено, что степень загрязнения окружающей среды химическими элементами, и в первую очередь тяжелыми металлами, определяется относительно фонового содержания элементов или предельно допустимой концентрации. Выявлено, что основными загрязняющими металлами, которые могут негативно влиять на хозяйственную деятельность в прилегающих территориях и способствовать негативному влиянию на здоровье человека, является цинк и хром. Установлена оценочная шкала опасности загрязнения ландшафтов автозаправочными станциями. Предложено для повышения экологической безопасности автозаправочных станций осуществлять постоянный мониторинг почвенного покрова в пределах санитарно защитной зоны и на прилегающих территориях, ужесточить требования к очистным и ресурсосберегающих систем и обеспечить выполнение плана обязательной периодической технической диагностики оборудования автозаправочных станций.
\end{abstract}

Ключевые слова: автозаправочные станции; тяжелые металлы; фоновая концентрация; загрязненные почвы; загрязняющие вещества; полютанты.

\author{
O. G. Chaika1, O. O. Matskov', O. M. Stokalyuk', M. V. Ruda' \\ ${ }^{1}$ Lviv Polytechnic National University, Lviv, Ukraine \\ ${ }^{2}$ Lviv State University of Life Safety, Lviv, Ukraine
}

\section{STUDY OF HEAVY METALS CONTENT IN THE SOIL OF ADJACENT TERRITORIES OF PETROL STATIONS}

The content of heavy metals in the soil of adjacent areas of filling stations is determined. The contamination of the earth surface by vehicle emissions near or at a filling station is found to accumulate gradually, depending on the number of vehicles passing through the adjacent track, road, and highway and enter directly the filling station, and last for quite a long time even after the elimination of the roadway. Improving environmental and disaster safety in the operation of filling stations along with the implementation of measures to reduce water and soil pollution require monitoring of concentrations of hazardous substances to prevent excess health, environmental, and explosive norms. It is obvious that the absolute requirement to operation of filling stations is to assess the environmental impact of pollutants, determining their concentrations. It is revealed that the degree of environmental pollution by chemical elements, especially heavy metals, is determined to be relative to the background content of elements or the maximum allowable concentration. The major polluting metals, which can have a negative impact on economic activity in adjacent areas and contribute to the negative impact on human health, are defined to be zinc and chromium. The scale of the danger of pollution of landscapes by filling stations is obtained. The authors propose to improve the environmental safety of filling stations, implement permanent monitoring of soils within the sanitary protection zone and in adjacent areas, tighten requirements for pollution-reducing and resource-saving systems and ensure the implementation of the mandatory periodical technical diagnostics of the equipment of filling stations. Having analysed the data obtained, we can note that the highest concentration of zinc detected in surface soil samples. With a high degree of soil pollution being not only a process of change and rebalancing of microorganisms, which differs from the uncontaminated, but the changes in some chemical and physical soil properties. According to the calculations we have found that the main polluting elements that may have a negative impact on economic activity in adjacent areas of filling stations and contribute to a negative impact on human health.

Keywords: filling stations; heavy metals; background concentration; contaminated soil; pollutant. 